\title{
СУЇЦИДАЛЬНА НАЛАШТОВАНІСТЬ ЯК ПРОЯВ САМОРУЙНІВНОЇ ПОВЕДІНКИ У РОБІТНИЦЬ КОМЕРЦЙНОГО СЕКСУ
}

\section{Потоцька Ірина Сергївна}

Доцент, кандидат психологічних наук, доцент кафедри медичної психології та психіатрії з курсом післядипломної освіти Вінницького національного медичного університету ім. М. І. Пирогова, м. Вінниия (Україна)

\section{Гришина Ольга Валерївна}

Психолог «Комюніті иентр для робітниць комериіийнго сексу» на базі Всеукраӥнського благодійного фонду «ДропінЦентр», м. Вінниия (Україна)

\begin{abstract}
Анотація. Досліджено фактори, щуо сприяють виникненню суїицдальних думок серед робітниць комериійного сексу. Емпіричне дослідження проводилось з використанням «Колумбійської икали важкості суїциду (C-SSRS)», яка виявляє і стандартизує суїцидальні думки та поведінку. Встановлено, щуо основними суйцидальними ідеями робітниць комерційного сексу $\epsilon$ думки про смерть та загальні неспециифічні думки про бажання накласти на себе руки. Основними підставами таких суїидальних ідей є як бажання привернути увагу інших людей так i бажання зупинити свій психологічний біль. Дві третини мали у власному досвіді зупинені спроби скоєння самогубства.
\end{abstract}

Ключові слова: робітниці комеричійного сексу, суйицдальна налаштованість, саморуйнівна поведінка.

\section{Постановка проблеми у загальному} вигляді. Останні роки Україна зіткнулася 3 серйозними соціально-економічними потрясіннями та кризами, що сприяють формуванню стресових та депресивних станів у населення країни [1]. Окрему соціальну, психологічну та медичну проблему сьогодення стано- влять суїциди [2-4]. Експерти Всесвітньої організації охорони здоров'я наводять дані про щонайменше 800 тис. осіб завершених суїцидів щороку, при цьому самогубство $є$ десятою за значимістю причиною смерті для всіх вікових груп і другою провідною причиною смерті у віковій групі 15-29 років [5]. 
Високі показники самогубств спостерігаються серед найбільш уразливих груп населення та осіб які піддаються дискримінації. Найчастіше це біженці та мігранти; ув'язнені та люди що звільнилися з місць позбавлення волі; представники ЛГБТ та робітниці комерційного сексу (РКС), оціночна кількість яких в Україні постійно зростає: $з$ близько 70 тис. у 2009 році до 80 тис. у 2012 році та близько 100 тис. у 2017 році [6-8]. Проституція стала вельми поширеним явищем у сучасному світі, вона пов'язана 3 широким колом моральноетичних та психічних девіацій, ризиком наркотизації та розповсюдження статевих інфекцій; і справляє суттєвий негативний вплив на суспільне здоров'я, тож закономірним є зростаючий науковий інтерес до вивчення психологічних проблем РКС, включаючи проблему самогубства [9-12].

Психічне здоров'я, на думку С. Д. Максименко «як аспект здоров'я взагалі, який підкреслює стан душевного комфорту, відсутність патологічних психічних проявів та здатності до ефективної діяльності і саморегуляції у відповідності до власних (відрефлексованих) цілей і інтересів людини», тому вибір саморуйнівного стилю життя (саморуйнівної поведінки) вказує на наявність психічних порушень, відхилення в емоційновольовій та мотиваційній сфері, хворобливого стану душі. Тому, що «процес діяльності взагалі є могутнім фактором здоров'я особистості - i соматичного, і психічного, і психологіч- ного»! Люди часто повільно вбивають себе (непрямий суїцид) обрав діяльність пов'язану 3 постійним ризиком для здоров'я та життя, набув шкідливі звички, не усвідомлюючи своїх летальних намірів і заперечують те, що їх дії направлені на саморуйнування або спричинення шкоди самим собі [13].

Калвін Фредерік з Американського Національного Інституту психічного здоров'я приводить сім основних характеристик непрямого суїциду: часта відсутність усвідомлення наслідків своїх вчинків; раціоналізація, інтелектуалізація або заперечення своєї поведінки; поступовий початок деструктивної поведінки, яка все ж наближає смерть; украй рідке відкрите обговорення цих тенденцій; вірогідність довготерпеливої мученицької поведінки; витягання вторинної вигоди із співчуття чи/і проявів ворожості під час саморуйнування; смерть майже завжди здається випадковою. Американський психолог Едвін Шнейдман в 1985 році вперше описав 10 загальних рис, властиві всім без виключення самогубствам, а саме: 1) Загальна мета всіх суїцидів - пошук рішення. Він не $є$ випадковою дією, його ніколи не роблять безглуздо або безцільно. 2) Загальним завданням всіх суїцидів $є$ припинення свідомості. Воно полягає в повному припиненні потоку свідомості нестерпного болю, що представляється вирішенням хворобливих життєвих проблем. 3) Загальним стимулом при суїциді $€$ нестерпний психічний (душевний) біль. Якщо припинення свідомос- 
ті - це те, до чого прагне суїцидент, то нестерпний психічний (душевний) біль є тим, від чого він втікає. Біль це загроза життю, а загроза існування виходить від болю емоцій, а саме зі свідомості людини. Тому психічний біль $\epsilon$, як писав Е. Шнейдман, метабіль, біль від усвідомлення болю, душевне страждання або мука особи. Коли людина іiі відчуває, його інтрапсихічний стан стає нестерпним. 4) Загальним стресором при суїциді є фрустровані психологічні потреби. Суїцид не безглуздий і необгрунтований вчинок - він здається логічним людині, що здійснює його, на підставі логічних передумов, образу мислення і зосередженості на певному крузі проблем і $є$ реакцією на фрустровані вітальні потреби. 5) Загальною суїцидальною емоцією є безпорадність - безнадійність. Часто вважається, що ворожість, гнів, як і інші сильні емоції, наприклад сором або провина, зустрічаються під час суїциду, проте за ними завжди знаходиться базисне відчуття внутрішньої спустошеності, безпорадність безнадійність. Ця генералізована емоція проявляється сум-яттям і тривогою. 6) Загальним внутрішнім відношенням до суїциду є амбівалентність. Типовим для самогубства $є$ коли людина одночасно намагається знищити себе i бажає допомоги. 7) Загальним станом психіки $є$ звуження когнітивної сфери. Свідомість стає «тунельною», варіанти вибору поведінки різко обмежуються. 8) Загальною дією при суїциді є втеча (агресія). Воно відображає намір людини піти із зони лиха. 9) Загальним комунікати- вним актом при суїциді є повідомлення про намір. Люди, що мають намір зробити суїцид свідомо або несвідомо подають сигнали лиха: скаржаться на безпорадність, волають про підтримку, шукають можливості порятунку. 10) Загальною закономірністю суїциду є його відповідність загальному стилю поведінки в житті. «Коли ми стикаємося 3 самогубством, то нас спочатку збиває той факт, що воно за своєю природою є вчинком, якому немає аналогів і прецедентів в попередньому житті людини. Та все ж йому можна знайти глибокі відповідності в стилі і характері поведінки людини протягом всього життя. Загальною закономірністю є відповідність суїцидальної поведінки загальному стилю (патернам) поведінки протягом життя» [14].

С. Д. Максименко вважає, що жорстким регулятором поведінки є переконання. Їх підгрунтя становлять знання, які для людини є істинними, незаперечними, в яких вона не має сумніву. Особливість переконань полягає в тому, що в них знання постають в єдності 3 почуттями, захоплюючи всю особистість. Переконання $\epsilon$ там, де є страждання та муки сумління, коли порушуються принципи в діях i вчинках [15]. Розвиток суїцидальних реакцій та психотравмуючих ситуацій, пов'язаний 3 наявністю певних неадаптованих переконань: «Краще померти, чим так далі жити», «Я втомилась від життя», «Всім без мене буде краще», які в несприятливих умовах можуть приводити до виникнення суїциїдальної поведін- 
ки. Суїцидогенні переконання пов'язані з уявленням про більшу значущість, ніж власне життя, особисто-родинних або соціальнопрестижних цінностей і формуються під впливом виховання, психотравмуючих переживань і різних мікросоціальних дій та перешкоджають прийняттю оптимального способу виходу 3 кризових станів [16].

Аналіз останніх досліджень і публікацій.

Проституція (надання послуг сексуального характеру за гроші) пов'язана з великими ризиками для фізичного, психологічного та соціального здоров'я людини. Згідно визначенню ООН, насилля це надання фізичної, психологічної або економічної шкоди, примус або обмеження волі в будь-якій сфері життя. Згідно статистичним даним 95 \% РКС стикаються $з$ психологічним насильством упродовж року, що проявляється у формі приниження, нецензурної лайки, шантажу, погроз та залякування. Близько 89 \% РКС упродовж року стикаються 3 проявами сексуального насилля у формі змушування до сексуального акту в неприродніх формах та без використання презервативу. Від фізичного насилля постраждало 82 \% РКС. Їх змушували вживати алкоголь та наркотики, зачиняли на декілька днів у зйомних квартирах, били та ін. Майже половина досліджених 45 \% піддалися економічному насиллю. Їм не надавали оплати за надані послуги, відбирали отримані кошти а також їжу та одяг. Основними джерелами насилля для
РКС є клієнти, співробітники правоохоронних органів, інші РКС, батьки та родичі, чоловіки або співмешканці, роботодавці (сутенери або мамочки). Окрім різних форм насилля ризики РКС пов'язані і 3 можливістю інфікування ВІЛ та ІПСШ, небажаною вагітністю, вживанням наркотиків та алкоголю. Згідно статистики 11 \% РКС вживали наркотики перед або під час роботи за останні 30 днів та $90 \%$ РКС пили алкогольні напої [17-22].

Проституція - це ризикована поведінка, небезпечна для психічного та соматичного здоров'я, яку можна розглядати як діяльність, що веде до саморуйнування. Однією $з$ найпоширеніших форм реалізації саморуйнівної поведінки є суїцидальна активність.

Виходячи 3 цього, метою даної роботи стало вивчення суїцидальної налаштованості у робітниць комерційного сексу, для визначення мішені подальшої психокорекційної роботи 3 даним контингентом.

\section{Контингент і матеріали дослідження.}

Надавши інформовану згоду у дослідженні прийняли участь 85 жінок, мешканки міста Києва. Дослідження проводилось в «Комюніті центрі для робітниць комерційного сексу» на базі ВБФ «Дроп ін Центр».

Групу дослідження склали 85 жінок віком від 18 до 38, середній стаж заняття комерційним сексом $3,05+2,15$ роки. Середній вік початку сексуального життя 16,02+2,87 років, що не $\epsilon$ тотожнім віку отримання першого сексуального досвіду, бо більшість жі- 
нок розповідали про наявність сексуального насильства у дитинстві та суб'єктивно не сприймали це як початок сексуального життя. Серед них 43,0 \% мають вищу освіту, 57,0 \% середню/середньо спеціальну освіту.

Для встановлення наявності суїцидальності серед РКС нами було обрано та використано валідизовану і визнану надійним інструментом «Колумбійську шкалу важкості суїциду (C-SSRS)», яка виявляє і стандартизує суїцидальні думки і поведінку. Наявність суїцидальних думок класифікується по п'яти рівнях збільшення міри їх серйозності: пасивні думки, типа «хочу бути мертвим або лягти спати $\mathrm{i}$ не прокинутися» і чотири рівні активної думки, подібно до бажання накласти на себе руки, представлення методів самогубства, конкретний намір убити себе, розробка плану. Кожен пункт вимагає позитивної або негативної відповіді. У даному дослідженні відповідь давалась на наявність даних симптомів будь-коли у минулому.

\section{Результати дослідження.}

При емпіричному дослідженні суїцидальної налаштованості у РКС були отримані наступні результати, які відображають зміст та особливості суїцидальних ідей, підстав та поведінки.

На рисунку 1 відображені особливості суїцидальних ідей, які мають наступний опис: бажання померти (БП) - думки про бажання померти або перестати жити, або про бажання заснути і не прокинутися; активні неспецифіч- ні думки про самогубство (АНД) - загальні неспецифічні думки про бажання накласти на себе руки; актуальні суїцидальні ідеї, включаючи роздуми про спосіб самогубства, за відсутності наміру діяти (АСI роздуми) - думки про самогубство, роздуми про спосіб, але без конкретного плану дій; актуальні суїцидальні ідеї, включаючи деякий намір діяти, за відсутності конкретного плану (АСI намір) - активні думки про самогубство при заяві пацієнта про деякий намір діяти відповідно до цих думок; актуальні суїцидальні ідеї з конкретним планом і наміром (АCI план) - думки про самогубство, включаючи план з деталями і намір пацієнта здійснити цей план.

Наявність бажання «хочу бути мертвим або лягти спати і не прокинутися» виявлено у 81 жінки (95,2\%); 78 жінок(91,7\%) думали про те щоб здійснити самогубство; міркували про спосіб самогубства 29 жінок (34,1\%), але не мали конкретного плану, наміри діяти мали 18 жінок (21,1\%); У 40\% випадків суїциїдальні думки містили опрацювання способу і плану дій, мали намір здійснити детально розплановане самогубство.

Наступним етапом проводилося дослідження підстав суїцидальних ідей які відображені на Рисунку 2.

Результати дослідження підстав суїциїдальних ідей (Рис.2) виявили наступний розподіл: більшість 46 РКС (54,1\%) назвали бажання в рівній мірі привернути увагу і отримати відгук інших людей та припинити влас- 


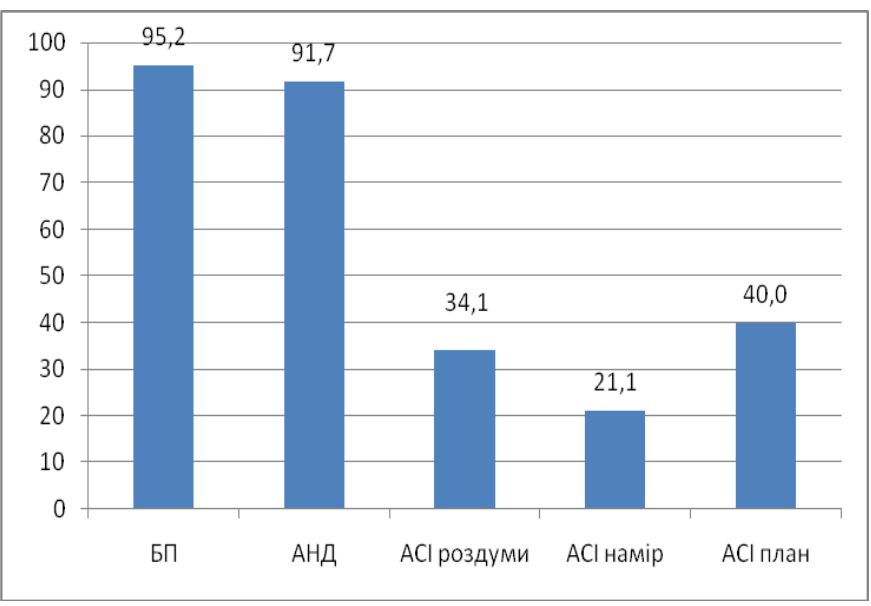

Рис. 1. Відсотковий прояв суїцидальних ідей у РКС

ний душевний біль. Рушійними емоціями суїцидального акту, як форми протесту, помсти, покарання «значимого іншого» чи кривдника в даному випадку є сором, гнів і образа. 18 РКС (21,2 \%) більшою мірою бажали зупинити біль бо не в змозі були продовжувати жити; 11 РКС (3,5 \%) бажали виключно привернути увагу. У представленні страждаючої інші способи привернути увагу вважалися не настільки дієвими; в 6 РКС (7 \%) - виявилося виняткове прагнення припинити душевний біль. Сенс цього суїцидального акту - це суїциїдальна спроба як отримання допомоги.

Відсотковий вияв суїцидальних дій РКС представлено на Рисунку 3.

Намагалися здійснити суїцид, виконавши підготовчі дії 34 РКС, що становить 40\% від усієї вибірки, але 23 РКС це 32,4\% від групи жінок, які намагалася здійснити суїцид зупинили себе самостійно. Їм допомогли релігійні переконання (віра що це великий гріх), думки про батьків чи дітей, страх, емоційне угамування під час підготовчих дій. У 11 жінок спроба самогубства була перервана зовнішніми обставинами, це були: дзвінок по телефону, втручання знайомих чи рідних що переконали не скоювати суїцид.

Висновки. Особливістю проституції як форми девіантної поведінки є те, що вона напряму пов'язана з іншими видами соціальних відхилень, такими як наркоманія, алкоголізм, соціальним паразитизм, злочинність, адміністративні правопорушення, аморальна поведінки та самогубство (суїцид).

Отримані результати емпіричного дослідження показали наявність майже у всієї ви-

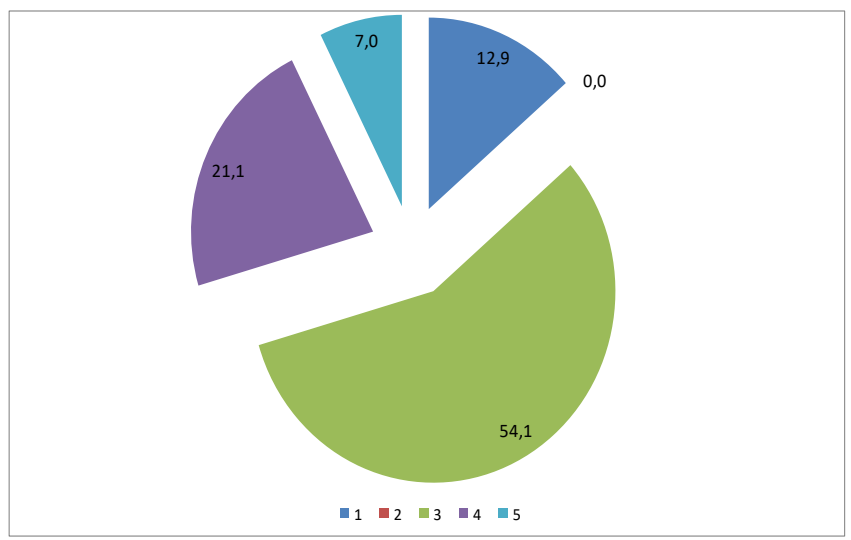

Рис. 2. Відсотковий розподіл підстав суїцидальних ідей серед РКС

де: 1 - виключно для того, щчоб припинити / зупинити біль (не в змозі продовжувати жити відчуваючи таку біль чи те, що відчували; 2 - більшою частиною для того, щяоб привернути увагу, помститися чи отримати відгук інших людей; 3 - у рівній мірі для того, щсоб привернути увагу, помститися чи отримати відгук інших людей та для того, щчоб припинити / зупинити біль; 4 - більшою частиною для того, щоб припинити / зупинити біль ( не в змозі продовжувати жити відчуваючи таку біль чи те, щчо відчували; 5 - виключно для того, щоб припинити / зупинити біль (не в змозі продовжувати жити відчуваючи таку біль чи те, щчо відчували. 
бірки досліджуваних РКС думок про скоєння суїциду,наявність бажання заснути і не проки-

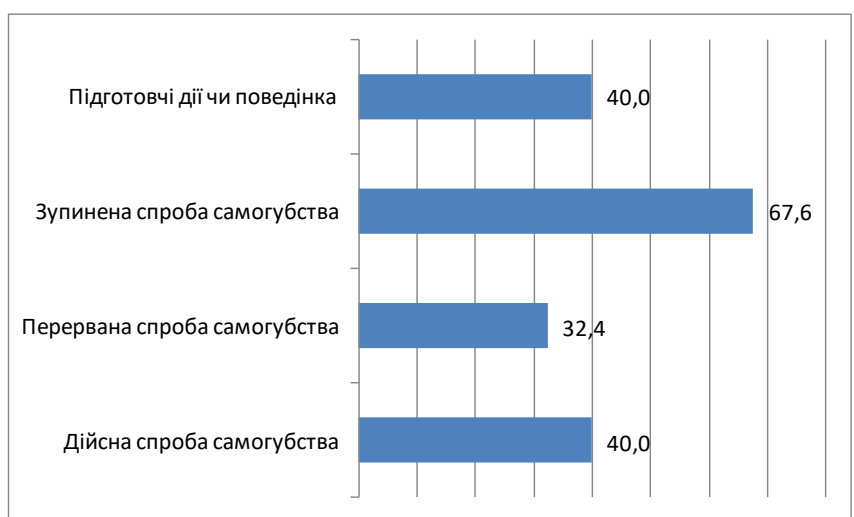

\section{Рис. 3. Відсотковий вияв суїцидальних дій серед РКС у \%}

датися та припинити своє існування. Також майже всій вибірці властиві загальні неспецифічні думки про бажання накласти на себе руки. Основними підставами таких суїцидальних ідей $є$ як бажання привернути увагу, помститися чи отримати відгук від інших людей так і бажання зупинити свій психологічний біль. При дослідженні суїцидальних дій серед РКС виявлено що дві третини РКС мали у власному досвіді зупинені спроби скоєння самогубства.

Отже, отримані результати показали наявність антивітальних тенденцій у жінок, які займаються проституцією, $\epsilon$ важливим переживанням в їх житті. Підстави можуть бути самими різними, від відмови від опору перед непереборними труднощами, привернення уваги, помсти до бажання покінчити 3 постійними болісними душевними переживаннями, але треба відмітити, що чинники ри- зику суїциду у кожному конкретному випадку здібні до кумулятивної та синергетичної взаємодії. Також результати вказують на високий ризик скоєння самогубства серед жінок цієї групи.

\section{Перспектива подалыших досліджень.} Дане дослідження відкриває перспективи в профілактиці суїциїдальної налаштованості та саморуйнівної поведінки у робітниць комерційного сексу.

Перелік використаних джерел:

1. Пиук Н. Г., Потоцька І.С., Белов О.О. Деякі аспекти патоморфозу циркулярних депресивних розладів на сучасному етапі. - Запорожский медицинский журнал. 2017. T. 19, № 3. С. 323-327.

2. Пиук Н. Г., Маркова М.В., Белов О.О. Щодо профілактики суїцидальної поведінки у студентської молоді з соціальними фобіями / Сучасні проблеми суїцидології: колективна монографія за ред. проф. Волошина П. В., проф. Марути Н. А. - Харків, 2017. C. 220-241.

3. Глинский Я. И. Самоубийство как социальное явление. Проблемы борьбы с девиантным поведением. Москва, 1989. С. 44-68.

4. Гроллман Э. Суицид: превенция, интервенция, поственция. Суицидология: прошлое и настоящее: Проблема самоубийств в трудах философов, социологов, психотерапевтов и в художественных текстах. - Москва, Когито-Центр, 2001. С. 270-352.

5. Suicide: Fact cheet. - World Health Association, Geneve, 2017. 32 p.

6. Потоиька I. С., Клименко Д. Ю. Суїцидальна поведінка наркозалежних особистостей. Дискурс здоров'я в освіті: філософія, педагогіка, антропологія, психологія / Міністерство освіти і науки України, НАПНУ, 
КВНЗ «Вінницька академія безперервної освіти», Міжнародна академія екології і здоровя, м.Вільнюс, Латвія, Мелітопольський державний педагогічний університет ім. Б. Хмельницького. - Вінниця: ТОВ «Планер», 2016. С. 158-160.

7. Глинский Я. И. Девиантология: социология преступности, наркотизма, проституции, самоубийств и других «отклонений». - Санкт-Петербург, Изд-во «Юридический центр Пресс». 2004. 287 с.

8. Балакірєва О., Андрущак Л., Варбан М. Діяльність громадських організацій по профілактиці ВІЛ / СНІДу серед жінок секс-бізнесу: За результатами проекту «Створення мережі неурядових організацій, які працюють із жінками секс-бізнесу в Україні». - Київ, Український інститут соціальних досліджень, 2000. 176 c.

9. Варбан М., Шульга Л., Демченко И., Белоносова Н. Жизнь уязвимых к ВИЧ людей: потребителей инъекционных наркотиков, женщин секс-бизнеса, мужчин, практикующих секс с мужчинами. - МБФ «Международный Альянс по ВИЧ/СПИД в Украине». Киев, 2014. 52 с.

10. Саранков Ю. Проблемы секс-бизнеса в контексте общественного здравоохранения. - Киев, «СПИД Фонд Восток - Запад», 2009. 128 с.

11. Балакірєва О. М., Бондар Т .В., Галустян Ю. М. Секс-бізнес в Україні: спроба соціального аналізу. Київ, Український інститут соціальних досліджень, 2001. 159 c.

12. Шиделко $A$. В. Проституція як крайній прояв статевої деморалізації // Соціальні технології: актуальні проблеми теорії та практики. - 2011. № 50. С. 434-441.

13. Загальна психологія. / За загальною редакцією академіка С.Д.Максименка. Підручник. - 2-ге вид., переробл. і доп. - Вінниця: Нова Книга, 2004. - 704 с.

14. Моховиков $A$. Суицидальный клиент: взгляд гештальт-терапевта // Суицидология: прошлое и настоящее: Проблема самоубийства в трудах философов, социологов, психотерапевтов и в художественных текстах. - Москва, 2001. С. 453-462.
15. Максименко С. Д. Розвиток психіки в онтогенезі. Том 1. Київ, «Форум», 2002. 319 с.

16. Максименко С. Д. Основи генетичної психології. Київ, 1998. 218 с.

17. Змановская Е. В. Девиантология: психология отклоняющегося поведения: учебник для студентов высших учебных заведений. - Москва, Издательский центр «Академия», 2003. 288 с.

18. Кучерук О., Пилипчук Н., Протопопов А. Зменшення шкоди: Концепция, практика, досвід України.- Київ, BACB, 2002. 112 c.

19. Herman J. L., Farley M. Introduction: hidden in plain sight: clinical observations on prostitution. In: Prostitution, Trafficking and Traumatic Stress, Binghamton, N.Y.: Haworth Press, 2013. P. 212-219.

20. Farley M. Prostitution Is Sexual//Times Violence Psychiatric. 2004. Vol. XXI, Issue 12. P. 78-80.

21. Flexsner A. Prostitution in Europe. New York: Century, 1914. P.18

22. Winick C., Kinsir P. The Lively Commerce: Prostitution in the US.- Chicago: Quadrangle Books, 1971. P. 3.

\section{References (Transliteration):}

1. Pshuk N. G., Pototska I.S., Belov O.O. DeyakI aspekti patomorfozu tsirkulyarnih depresivnih rozladIv na suchasnomu etapI. - Zaporozhskiy meditsinskiy zhurnal. 2017. T. 19, \# 3. S. 323-327.

2. Pshuk N. G., Markova M.V., Belov O.O. Schodo profilaktiki suyitsidalnoyi povedinki u studentskoyi molodi $\mathrm{z}$ sotsIalnimi fobiyami / Suchasni problemi suyitsidologiyi: kolektivna monografiya za red. prof. Voloshina P. V., prof. Maruti N. A. - Harkiv, 2017. S. 220-241.

3. Glinskiy Ya. I. Samoubiystvo kak sotsialnoe yavlenie. Problemyi borbyi s deviantnyim povedeniem. - Moskva, 1989. S. 44-68.

4. Grollman E. Suitsid: preventsiya, interventsiya, postventsiya. Suitsidologiya: proshloe i nastoyaschee: Problema samoubiystv $\mathrm{v}$ trudah filosofov, sotsiologov, psihoterapevtov i v hudozhestvennyih tekstah. - Moskva, Kogito-Tsentr, 
2001. S. 270-352.

5. Suicide: Fact cheet. - World Health Association, Geneve, 2017. $32 \mathrm{r}$.

6. Pototska I. S., Klimenko D. Yu. SuYitsidalna povedInka narkozalezhnih osobistostey. Diskurs zdorov'ya v osvitI: fllosoflya, pedagogIka, antropologIya, psihologIya / MInIsterstvo osviti I nauki UkraYini, NAPNU, KVNZ «VInnitska akademIya bezperervnoYi osvIti», MIzhnarodna akademIya ekologIYi I zdorovya, m.VIlnyus, LatvIya, MelItopolskiy derzhavniy pedagogIchniy unIversitet Im. B. Hmelnitskogo. - VInnitsya: TOV «Planer», 2016. S. 158160.

7. Glinskiy Ya. I. Deviantologiya: sotsiologiya prestupnosti, narkotizma, prostitutsii, samoubiystv i drugih «otkloneniy». - Sankt-Peterburg, Izd-vo «Yuridicheskiy tsentr Press». 2004. $287 \mathrm{~s}$.

8. Balakireva O., Andruschak L., Varban M. DIyalnIst gromadskih organIzatsIy po profIlaktitsI VIL / SNIDu sered zhInok seks-bIznesu: Za rezultatami proektu «Stvorennya merezhI neuryadovih organIzatsIy, yakI pratsyuyut Iz zhInkami seks-bIznesu v UkraYinI». - KiYiv, UkraYinskiy Institut sotsIalnih dosIIdzhen, 2000. $176 \mathrm{~s}$.

9. Varban M., Shulga L., Demchenko I., Belonosova N. Zhizn uyazvimyih k VICh lyudey: potrebiteley in'ektsionnyih narkotikov, zhenschin seks-biznesa, muzhchin, praktikuyuschih seks $\mathrm{s}$ muzhchinami. - MBF «Mezhdunarodnyiy Alyans po VICh/SPID v Ukraine». Kiev, 2014. 52 s.

10. Sarankov Yu. Problemyi seks-biznesa v kontekste obschestvennogo zdravoohraneniya. - Kiev, «SPID Fond Vostok - Zapad», 2009. 128 s.

11. BalakIrEva O. M., Bondar T .V., Galustyan Yu. M. Seks-bIznes v UkraYinI: sproba sotsIalnogo analIzu. KiYiv, UkraYinskiy Institut sotsIalnih doslIdzhen, 2001. $159 \mathrm{~s}$.

12. Shidelko A. V. ProstitutsIya yak kraynIy proyav statevoYi demoralIzatsIYi // SotsIalnI tehnologIYi: aktualnI problemi teorIYi ta praktiki. - 2011. \# 50. S. 434-441.

13.Zagalna psihologIya. / Za zagalnoyu redaktsIEyu akademIka S.D.Maksimenka. PIdruchnik. - 2-ge vid., pererobl.
I dop. - VInnitsya: Nova Kniga, 2004. - 704 s.

14. Mohovikov A. Suitsidalnyiy klient: vzglyad geshtaltterapevta // Suitsidologiya: proshloe i nastoyaschee: Problema samoubiystva $\mathrm{v}$ trudah filosofov, sotsiologov, psihoterapevtov i v hudozhestvennyih tekstah. - Moskva, 2001. S. 453-462.

15.Maksimenko S. D. Rozvitok psihIki v ontogenezI. Tom 1. KiYiv, «Forum», 2002. $319 \mathrm{~s}$.

16.Maksimenko S. D. Osnovi genetichnoYi psihologIYi. KiYiv, 1998. $218 \mathrm{~s}$.

17. Zmanovskaya E. V. Deviantologiya: psihologiya otklonyayuschegosya povedeniya: uchebnik dlya studentov vyisshih uchebnyih zavedeniy. - Moskva, Izdatelskiy tsentr «Akademiya», 2003. $288 \mathrm{~s}$.

18. Kucheruk O., Pilipchuk N., Protopopov A. Zmenshennya shkodi: Kontseptsiya, praktika, dosvId UkraYini.KiYiv, VASV, 2002. $112 \mathrm{~s}$.

19. Herman J. L., Farley M. Introduction: hidden in plain sight: clinical observations on prostitution. In: Prostitution, Trafficking and Traumatic Stress, Binghamton, N.Y.: Haworth Press, 2013. P. 212-219.

20. Farley M. Prostitution Is Sexual//Times Violence Psychiatric. 2004. Vol. XXI, Issue 12. P. 78-80.

21. Flexsner A. Prostitution in Europe. New York: Century, 1914. P.18.

22. Winick C., Kinsir P. The Lively Commerce: Prostitution in the US.- Chicago: Quadrangle Books, 1971. P. 3.

\section{Iryna Pototska}

PhD in Psychological Sciences, assistant professor, assistant professor of the Department of Medical Psychology and Psychiatry with the course of postgraduate education of Pirogov Vinnitsa National Medical University, Vinnitsa (Ukraine)

\section{Grishina Olga}

Psychologist of "Communicative Center for Workers of Commercial Sex" on the basis of the All-Ukrainian Charity Fund "Drop In Center", Vinnitsa (Ukraine)

\section{SUICIDAL TENDENCY AS A MANIFESTA-}




\section{TION OF SELF-DESTRUCTIVE BEHAV- IOR IN WORKERS OF COMMERCIAL SEX}

\section{ABSTRACT}

The purpose of the work is to study suicidal tendency in workers of commercial sex, to determine the target of further psychocorrectional work with this contingent.

Contingent and research methods. The study was conducted at the Community Center for Workers of Commercial Sex on the basis of the All Ukrainian Charity Fund "Drop In Center", which, withan informed consent, surveyed 85 women-workers of commercial sex, residents of the city of Kiev. To establish suicidal tendency, it was used a well-trusted instrument, Columbia Suicide Severity Rating Scale (C-SSRS) which detects and standardizes suicidal thoughts and behavior.

Results of the study. The obtained results of the empirical research showed that almost all the surveyed workers of commercial sexhave thoughts about committing suicide, the desire to fall asleep and not to wake up and to cease to exist. Also, almost all of the sample is characterized by general non-specific thoughts about the desire to commit suicide. The main causes of such suicidal ideas are the desire to attract attention, revenge or get a feedback from other people, and the desire to stop their psychological pain. In the study of suicidal actions among workers of commercial sex, it was found that two thirds of work- ers of commercial sex had stopped attempts to commit suicide in their own experience.

Consequently, the results indicated the presence of anti-vital tendencies in women who work as prostitutes, which are an important emotional experience in their lives. The bases can be very different, from refusal to resist the inevitable difficulties, to attract attention, to revenge, to the desire to end the infinite painful mental experiences, but it should be noted that the risk factors of suicide in each case are capable of cumulative and synergistic interaction. Also, the results indicate a high risk of committing suicide among women in this cohort.

Conclusion. This study reveals prospects in preventing suicidal tendency and selfdestructive behavior in workers of commercial sex.

Key words: workers of commercial sex, suicidal tendency, self-destructive behavior.

\section{Потоцкая Ирина Сергеевна}

Кандидат психологических наук, доиент, доиент кафедры медицинской психологии и психиатрии с курсом последипломного образования Винниикого национального медицинского университета им. Пирогова, Винница (Украина)

\section{Гришина Ольга Валерьевна}

Психолог «Комьюнити иентр для работниц коммерческого секса» на базе Всеукраинского благотворительного фонда «ДропинЦентр», г. Винница (Украина)

\section{СУИЦИДАЛЬНАЯ НАСТРОЕННОСТЬ КАК ПРОЯВЛЕНИЕ \\ САМОРАЗРУШАЮЩЕГО ПОВЕДЕНИЯ У РАБОТНИЦ КОММЕРЧЕСКОГО CEКСА}


Аннотация. Исследованы факторы, способствующие возникновению суицидальных мыслей среди работниц коммерческого секса. Эмпирическое исследование проводилось с использованием «Колумбийской шкалы тяжести суицида (C-SSRS)», которая обнаруживает и стандартизирует суицидальные мысли и поведение. Установлено, что основными суицидальными идеями работниц коммерческого секса мысли о смерти и общие неспецифические мысли о желании покончить с собой. Основными основаниями таких суицидальных идей является как желание привлечь внимание других людей так и желание остановить свой психологический боль. Две трети имели на личном опыте остановлены попытки совершения самоубийства.

Ключевые слова: работницы коммерческого секса, суицидальная настроенность, саморазрушительное поведение. 